\title{
Tækjabúnaður Landspítala: umhyggja - fagmennska - öryggi - frampróun?
}

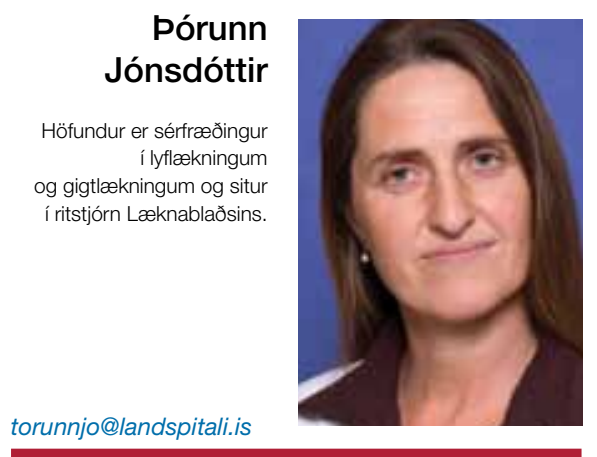

Landspítali hefur valið slagorðin umhyggja - fagmennska - öryggi - frampróun í stefnumörkun sinni. Pessi orð fela í sér pau gildi sem spítalinn vill hafa að leiðarljósi og vinna eftir. Pegar horft er til tækjabúnaðar spítalans koma pessi slagorð pó sérfræðingi sem nýkominn er til starfa á Landspítala nokkuð spánskt fyrir sjónir.

Sem nýliði á sjúkrahúsinu hef ég furðað mig á tækjum eða öllu heldur á tækjavanda spítalans og mér hefur gengið illa að finna góðan tækjabúnað við vinnu mína. Sérgrein mín er pó ekki ein peirra sem parf að reiða sig hvað mest á tæknina. Engu að síður hef ég ekki farið varhluta af tækjaog tæknivanda spítalans. Jafn einfalt verk eins og að mæla blóðprýsting sjúklinga minna á göngudeildinni virðist ekki sjálfsagt. Mælarnir virka ekki, manséttur eru slitnar, leka, eru í röngum stærðum og par fram eftir götunum. Að geta skoðað î eyru sjúklinga sem liggja á sjálfri háls-, nef- og eyrnadeild Landspítala er heldur ekki alltaf sjálfgefið. Nýverið lá einn sjúklinga minna par og var meðal annars með heyrnarskerðingu sem hafði versnað. Ég ætlaði ásamt aðstoðarlæknum mínum að gera góða og faglega skoðun og meðal annars skoða inn í eyrun. Ekki tókst pó betur til en svo að senda purfti sjúklinginn að endingu niður á sérstaka göngudeild til HNE-sérfræðinga pví engar fundust "græjurnar" á legudeildinni - sem sagt ekkert eyrnaspeglunartæki á HNE-deild! petta eru kannski smáhlutir en staða peirra gefur pó tóninn í stærra samhengi.

Á bráđamóttökudeildum er að mér skilst hrópandi vöntun á betri tækjabúnaði til að fylgjast með lífsmörkum bráðveikra sjúklinga (monitoreftirlit). Í fyrsta lagi er ekki að finna slíkan sjálfsagðan búnað í öllum bráđaplássum eins og vera ber á háskólasjúkrahúsi. Í öðru lagi er ekki alltaf möguleiki á að hafa eftirlit úr svokallaðri móðurstöð í vaktherbergi, úr peim búnaði sem pó er til staðar. Petta verður að teljast óásættanlegt og getur vart flokkast undir öryggi eða fagmennsku, hvað pá frampróun.

Hvar er fagmennskan og öryggið pegar hjartaómunartæki Landspítalans í Fossvogi er svo lélegt að illa gengur að reiða sig á niðurstöðurnar? Hvar er umhyggjan, fagmennskan og öryggið pegar verið er að peysast með sjúklinga í rannsókn sem gefur mun ónákvæmari svör en við vitum að við getum fengið úr betra tæki. Ég hef oftar en einu sinni lent í að endurtaka parf sömu rannsókn á betra hjartaómunartæki á spítalanum á Hringbraut. Ég hef spurt mig hvort ekki hefði verið betur heima setið en af stað farið pegar ég les svör eins og: ... ekki er með vissu hægt að útiloka ... vegna lélegra ómskilyrða ... ef áfram er klínískur grunur um ... er mælt með endurtekinni skoðun á hjartaómun á Hringbraut. Раð hlýtur að vera ópolandi fyrir okkar færu hjartalækna að sitja með svo lélegt tæki í höndunum - er ekki verið að fara með dýrmætan tíma vel menntaðs og pjálfaðs fólks til spillis pegar sett eru í hendurnar á fólki úrelt tæki í Fossvogi?

Talið er löngu tímabært að endurnýja geislatæki krabbameinsdeildanna. Getum við talað um fagmennsku og frampróun pegar notuð eru 16 ára gömul tæki pegar stærri sjúkrahús nágrannalandanna eru fyrir allmörgum árum búin að verða sér úti um mun betri og nákvæmari tæki. Tæki sem gefa nákvæmari geislun og par af leiðandi sennilega betri árangur og minni aukaverkanir. Getum við fullyrt við sjúklinga okkar að peir fái bestu og öruggustu pjónustu sem völ er á? Erum við á braut frampróunar?

Tölvukostur og hugbúnaður sjúkrahússins er kapítuli út af fyrir sig. Ég hef margsinnis reytt hár mitt yfir hægfara og biluðum tölvum og úreltum hugbúnaði. Nú í sumar hefur um helmingur tölvanna á minni deild verið bilaður. •að er sorglega mikil sóun á tíma sem fer í að finna tölvu sem virkar, bíða eftir hægfara tölvum/kerfum, finna prentara sem venjulega eru staðsettir langt frá peirri tölvu par sem verið er að vinna og svo framvegis. Á vinnufundum fer alltof mikill tími í að láta tæknina virka pannig að fundir verða oft óparflega óskilvirkir ... og enn er margt ótalið.

Slagorð spítalans eru góð og gild og bera sennilega með sér pau gildi sem hver starfsmaður innan sjúkrahússins vill vinna að í sínu starfi. En hvað varðar tækjabúnað og tæknimál Landspítala hljóma pau enn sem komið er í mínum eyrum sem innantóm stafaruna. Við leggjum mikið á okkur í tíma og fjármagni við að mennta gott fólk og próa læknavísindin. Ég efast um að mikill sparnaður geti falist í að spara svo á sviði tækja og tækni sem nú er raunin verður slíkur sparnaður ekki á endanum að aukakostnaði? Mér sýnist að of víða á Landspítala séum við vegna fjársveltis komin að peim mörkum par sem við hendum krónunni og spörum aurinn.

Equipment in Landspítali University Hospital: Compassion-Professionalism-Safety-Progress? specialist in Internal Medicine and Rheumatology 